Instructions for authors, subscriptions and further details:

\title{
http://mcs.hipatiapress.com
}

\section{Representation of Javanese Masculinity in The Dangdut Songs Lyric}

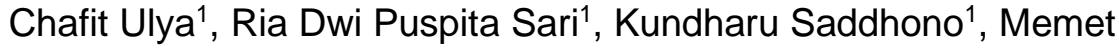
Sudaryanto $^{2}$

1) Universitas Sebelas Maret, Indonesia ${ }^{1}$

2)Universitas Jenderal Soedirman, Indonesia ${ }^{2}$

Date of publication: June $21^{\text {st }}, 2021$

Edition period: June 2021 - October 2021

To cite this article: Ulya, C., Dwi Puspita Sari, R., Saddhono, K, \& Sudaryanto, M. (2021). Representation of Javanese Masculinity in The Dangdut Songs Lyric. Masculinities and Social Change, 10 (2) 139-161. https://doi.org/10.17583/MCS.2021.5967

To link this article: https://doi.org/10.17583/MCS.2021.5967

PLEASE SCROLL DOWN FOR ARTICLE

The terms and conditions of use are related to the Open Journal System and to Creative Commons Attribution License(CC-BY). 


\title{
Representation of Javanese Masculinity in The Dangdut Songs Lyric
}

Chafit Ulya

Universitas Sebelas Maret

Kundharu Saddhono

Universitas Sebelas Maret
Ria Dwi Puspita Sari

Universitas Sebelas Maret

Memet Sudaryanto

Universitas Jenderal Soedirman,

\begin{abstract}
Modernization provides a major change in the structure of human life, including in relations between men and women in the marriage life. This change creates a new dimension of masculinity, including those found in the lyrics of dangdut koplo songs. This research was conducted to answer the question, what is the form of the new dimension that represents Javanese masculinity in the lyrics of dangdut koplo songs? This research uses descriptive qualitative method by using Jonet Saltzman Chafetz's concept of masculinity. Chafetz divides masculinity into six areas, namely physical, functional, sexual, emotional, intellectual, and impersonal. The research gives conclusion that the Javanese dangdut songs raise three dimensions of masculinity, namely functional, emotional, and intellectual. The functional dimension places men in the role of breadwinners. The emotional dimension places men in a person with high emotional stability and maturity. Meanwhile, the intellectual dimension presents a male figure with logical, rational, and realistic thoughts.
\end{abstract}

Keywords: masculinity, globalization, relations between men and women, dangdut koplo

2021 Hipatia Press

ISSN: 2014-3605

DOI: 10.17583/MCS.2021.5967 


\section{Representación de la Masculinidad Javanesa en las Letras de las Canciones de Dangdut}

Chafit Ulya

Universitas Sebelas Maret

Kundharu Saddhono

Universitas Sebelas Maret
Ria Dwi Puspita Sari

Universitas Sebelas Maret

Memet Sudaryanto

Universitas Jenderal Soedirman

\section{Resumen}

La modernización proporciona un cambio importante en la estructura de la vida humana, incluso en las relaciones entre hombres y mujeres en la vida matrimonial. Este cambio crea una nueva dimensión de masculinidad, incluida la que se encuentra en las letras de las canciones de dangdut koplo. Esta investigación se realizó para responder a la pregunta, ¿cuál es la forma de la nueva dimensión que representa la masculinidad javanesa en la letra de las canciones de dangdut koplo? Esta investigación utiliza un método cualitativo descriptivo utilizando el concepto de masculinidad de Jonet Saltzman Chafetz. Chafetz divide la masculinidad en seis áreas, a saber, física, funcional, sexual, emocional, intelectual e impersonal. La investigación llega a la conclusión de que las canciones dangdut javanesas plantean tres dimensiones de masculinidad, a saber, funcional, emocional e intelectual. La dimensión funcional coloca a los hombres en el papel de sostén de la familia. La dimensión emocional sitúa al hombre en una persona con alta estabilidad y madurez emocional. Mientras tanto, la dimensión intelectual presenta una figura masculina con pensamientos lógicos, racionales y realistas.

Palabras clave: masculinidad, globalización, relaciones entre hombres y mujeres, dangdut koplo 


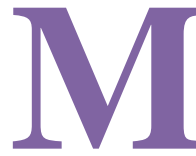

odernization provides major changes to the structure of human life, including the position of men and women in a marriage life. The patriarchal dominance of men found in married life has shifted or changed. This change creates a new dimension of masculinity.

This changing dimension of masculinity can be seen from the reduction in domestic violence done by men due to the relationship process between husband and wife (Bustamante et al., 2019). In fact, this new paradigm of masculinity has brought men to be involved in efforts to fight with gender violence against women (Joanpere \& Morlà, 2019).

The concept of masculinity always develops along with the dynamics of change in the society. It means the concept of masculinity is always influenced by culture (Barker, 2012). Traditionally, the concept of masculinity views force, power, fortitude, action, independence, self-satisfaction, solidarity, and work. In contrast, traditional masculinity looks down on interpersonal relationships, verbal abilities, domestic life, tenderness, communication, women, and children.

The image of a real man is characterized as a figure who is always changing. In the past, there was an assumption that real men must have character to never cry, always look tough, brave, strong, and muscular, and able to conquer the hearts of many women. In fact, real men are synonymous with cigarettes, alcohol, and violence (Donaldson, 1993). However, in the 1990s, masculinity was no longer determined by the notion of force, power, aggressiveness, but more emphasis on vulnerability, devotion, and caring. These aspects characterize a new type of masculinity (Prorokova, 2017).

Masculinity is not a derivative trait that is carried from birth. Masculinity is a cultural construction whose existence will be greatly influenced by the norms prevailing in the environment. Therefore, it is not surprising if in one study found a socio-cultural conclusion, the process of masculinity construction is carried out during childhood to adulthood (Albelda \& Infantes, 2017). Things relating to the habits, rituals, and customs of the community will form a concept of masculinity. This condition can be found in the way and taste in fashion, appearance, activity, how to solve problems, communication patterns, to the accessories worn (Vigorito \& Curry, 1998). 
Therefore, the concept of masculinity always undergoes a redefinition. Reconceptualization, redefinition, and the process of discovering new paradigms about masculinity are always relevant as study material. One interesting object that has a new concept of masculinity is found in the lyrics of dangdut songs. Specifically, on the lyrics of the dangdut koplo songs.

"Dangdut is the music of my country". The song, which was popularized by the Project Pop music group, emphasized that dangdut is one of the characteristics of Indonesian music. The United States has jazz, rap or hip hop, South America has a country, Jamaica has reggae, and Indonesia has dangdut.

Dangdut is an onomatopoeia or an imitation of the sound of a tabla musical instrument playing from India which produces the sound 'ndut' or a drum that sounds "dang". In short, dangdut can be defined as one of Indonesia's popular traditional music genres that specifically has Indian, Malay and Arabic musical elements (Muttaqin in Tandho \& Rohidi, 2018). The most prominent feature in dangdut music is the bang of tabla and drum instruments. Dangdut music is also strongly influenced by classical Indian and Bollywood music.

Starting in the 1970s, dangdut could be said to have matured in its modern form. As a popular music, dangdut is very open to the influence of other types of music, ranging from styles, keroncong, gambus, rock, pop, even house music. From that era until the present time, dangdut music has continued to develop following the times and market tastes.

One of the developments of dangdut music is koplo. Koplo or dangdut koplo music is a sub-genre of the dangdut genre. The hallmark of Koplo music is rhythm with a faster tempo. The Malay Orchestra group who dominated the musical stage of the Java Island region, especially East Java and Central Java, popularized this genre. Early appearance is usually called as dangdut pantura (means north coast).

Dangdut Koplo is the development of dangdut music in the 1990s, especially after the reformation. The term dangdut koplo is adopted from the word "koplo" which is identical to drug. The music rhythm that is presented dangdut koplo has almost the same effect as people who take koplo pills or extacy (Weintraub, 2013). Dangdut koplo is also synonymous with erotic rocking, sexy dressed singers, and sawer or tip from the audience (Amzy et al., 2019). Therefore, Koplo dangdut is much liked by men, especially those who are looking for entertainment due to various problems, usually related to 
marriage problems. Dangdut Koplo also presents lyrics that represent the feelings of men in general, especially those from the lower middle class.

The lyrics in this dangdut koplo song turned out to be a representation of the masculinity of Indonesian men. The lyrics of the dangdut koplo song, which were mostly created by male authors, present a new dimension of masculinity. He is able to represent men's feelings due to family problems. In these dangdut koplo songs, different concepts of masculinity are found, which are far different from the traditional Javanese masculinity known as the symbol of men who protect, dominate, and control, becoming men who prioritize patience, love, and loyalty in order to maintain the integrity of the family or marriage.

In the traditional masculinity concept of Javanese society, the ideal man is one who has a benggol (money) and a bonggol (sexual virility). Meanwhile, women belong to men, parallel to bandha (treasure), griya (palace), turangga (vehicles), kukila (birds, pets, sounds), and pusaka (weapons, powers). Dominance over women (wife) is a symbol of a man's virility. Conversely, in women there is no independence. Obedience, dependency, and submission of women to men is a picture of the glory of a Javanese woman's characteristics.

The concept of traditional masculinity places men as superior figures to women (Olson et al., 2013) in various aspects of life, both domestic and public. The hegemony of men over women is also legitimized by the values prevailing in society, both social values, religion, law, and so on. Some dogmas embedded in Javanese society about the superiority of men to women, for example, the term swarga nunut neraka kaut which means women follow men or husband either the men go to heaven or hell. There is also the term of kanca wingking which shows the domestic role of the wife with the main task of 3M (masak or cooking, macak or dressing, manak or breeding) or the dapur / kitchen, pupur / make up, kasur / bed, and sumur / well which means deal with cleaning. Modernization tries to correct the concept of male hegemony which then shifts the characteristics of masculinity in men.

Finding new dimensions of masculinity in music or song lyrics is not a new case. There have been many studies that address this issue. In a study of the development of topics in country songs from the 1980s to the 2010s, it was found that the relatively consistent aspects of masculinity raised in country songs spoke about men's work and heterosexuality tendencies (Leap, 2019). 
The study of pop song lyrics in the United Kingdom also found differences in the content between song lyrics sung by women and men. Song lyrics sung by women tend to describe the main things about the values of virtue, about inspiration and motivation. Conversely, song lyrics sung by male singers tend to discuss stereotypical concepts about adolescent masculinity (Krause \& North, 2019).

A very different thing is found in rap songs, where the content is still dominated by the concept of masculinity of black men. Violence, glamorous life, and hegemony of black men characterize masculinity in rap songs (Oware, 2011). In fact, the topic of violence has increased significantly in this rap song (Herd, 2009).

Dangdut musician's singing personality can change if one is faced with a gender perspective. Male dangdut singers will position themselves more loosely in the public. This shows that the image that created by male singers leads to self-esteem and the dynamics of masculinity. In accordance with Decker's explanation which emphasizes the singing personality of a woman who is required to change her self-image towards an Islamic or classical Malay form in order to show herself more valued (Decker, 2020).

Looking at the dynamic changes in the concept of masculinity in the song lyrics above, the study of the dimensions of masculinity in the dangdut koplo songs is something interesting to study. In the writer's notes, the lyrics of the dangdut koplo songs have unique characteristics and characteristics in presenting the issue of masculinity.

Dangdut has formed into a stereotype as vulgar music performed by many female singers who perform in their glamorous appearance and sexual exposure in the music industry, but this fact has brought dangdut into commercialization in the music industry (Setiawan \& Susanti, 2021). However, these stereotypes cannot be applied to male dangdut singers, they have privileges which are public's respect and positive view than female singers.

There is a paradigm shift in society about the role of men and women in Javanese society today which is represented in the lyrics of the dangdut koplo songs. Therefore, this study was conducted to answer the question of how the representation of Javanese masculinity in the lyrics of the dangdut koplo songs. 


\section{Research Methodology}

This research uses descriptive qualitative method by using Jonet Saltzman Chafetz's concept of masculinity. Chafetz divides masculinity into six areas, namely physical, functional, sexual, emotional, intellectual, and impersonal. The research data was collected from the dangdut koplo songs. Then data were analyzed with a content analysis approach, namely a research technique for making replicable and valid inferences from texts (or other meaningful matters) to the context of their use (Krippendorff, 2004). This research produces data in the form of written materials (Taylor \& Bogdan, 1998). The words were obtained from the lyrics of the dangdut koplo songs using notetaking techniques. Data were then analyzed using an interactive analysis model consisting of data collection, data reduction, data presentation, and verification or drawing conclusions (Miles \& Huberman, 1994).

\section{Representation of Javanese Masculinity}

In discussing the changing dimensions of masculinity in the dangdut koplo songs, the theory of Janet Saltman Chafetz was used. There are six characteristics of masculinity in men, namely (1) physical: male, athletic, strong, brave, unconcerned about the appearance and aging process; (2) functional: breadwinner, provider; (3) sexual: aggressive, experienced; (4) emotional: not emotional, always calm; (5) intellectual: logical, intellectual, rational, objective, practical; (6) interpersonal: leader, domineering, disciplined, independent, individualist (Campbell \& Chafetz, 2000). Among the six characteristics of masculinity above, in the dangdut koplo song, there are three characteristics of dominating masculinity, namely functional, emotional, and intellectual. The following is a complete description of the three characteristics of masculinity.

\section{Fungsional Dimension}

Functionally, men play a role as breadwinners, while wives play the role of financial managers (Nurlian \& Darulay, 2008). However, the modern era provides an additional portion of the role of women by placing it as a supporter 
of the family economy by working in an office or running a business at home (Putri \& Lestari, 2015). Apart from women's activities at work, the function of men as breadwinners is still one of the hallmark markers of masculinity found in the lyrics of the dangdut koplo songs.

One of the songs that elevates the role of men as breadwinners is "Aku Cah Kerja" or "I am a Working Person" created by Pendhoza. This song was built on three compositions, namely female singers, male singers and rap singers. This "Aku Cah Kerja" or "I am a Working Person" tells the story of a wife who is not willing to be left by her husband to work out of town. Life apart from her husband makes his wife feel suspicious and worried if her husband cheats on her. However, her husband managed to convince his wife that his departure was really intended to work for the future of the two of them.

This song highlights the dimension of masculinity at the functional level, namely the responsibility of a husband to find a living for the family. In the beginning, the feelings of the wife's feelings in the early days he left.

\section{Bebasan nunggu mangsa rendheng}

Anggonku lhe ngenteni kowe

Wes ana sesasi genep dina iki

(It's like waiting for the rainy season

I'm waiting for you

It's been a month by today)

The wife's anxiety is answered by the husband by saying that he really goes to work. The husband promises not to be tempted by another woman because in his heart, there is only his wife, no one else. Then in the last line, the husband reaffirmed his intention to go out of the city, which is to make a living, nothing else.

Dhik, lungaku ra teges cidra

Aku lagi pengen mikir kerja

Tak jaluk kowe aja kelara-lara

(Dhik, my going is not a lie

I want to think about work 
I ask you not to be hurt)

This part describes about the responsibility of a man as head of the family. The desire of a husband to find a decent living for his family is the main encouragement that causes him to be willing to be far apart from his wife. The husband realized that making a living is his duty (dongakna lakuku ngayahi kewajibanku - please pray for me to do my duty).

Pangapurane awakku ra tau nyanding sliramu

Mergo tuntutan kerjaku nganti ora nduwe wektu

Wektu kanggo ngancani uga ngeterke nyanyi

Kowe kudu ngerti lungaku golek rejeki

Dongakna lakuku ngayahi kewajibanku

Snajan abot kanggomu nanging kuatna atimu

Wes dadi kahanan aku lunga adoh paran

Ora bakal kelegan nyanding wedokan liyan

(I'm sorry I was unable to be by your side

Because the demands of work until there is no time

Time to accompany and to sing with you

You should know my going to look for living

Please pray for me to fulfill my duty

Even though it's hard for you but please be still

This is the why I $m$ being far

I will never be with another woman)

The rap music composition above comprehensively tells the husband's feelings when he is away from his wife. In that conditions, the wife is described as disappointed, sad, jealous, suspicious, and angry. The wife feels disappointed because the job prevents them from being together. The wife feels sad because she is worried that the husband will leave because there he loses his feeling. The wife feels jealous and suspicious for fear that her husband will be tempted by another woman. In addition, the wife is also often angry because their communication is less smooth due to bad connection.

The husband gave a full explanation of his wife's anxiety or worry by saying that his departure was purely for work. The husband hopes his wife 
understands the situation, prays for her husband's safety, and waits patiently for his return. The explanation of this husband was able to ease the fear of his wife. So, at the end of the song, his wife can understand and let her husband go to work. In addition, the wife entrusts a message to her husband to always be loyal and not to be tempted by other women.

Mas, yen pancen kuwi karepmu

Aku ya mung tansah bisa nunggu

Tak kuatne atiku tanpa sliramu

Mas, nadyan kowe lunga kerja

Sing tak jaluk kowe tetep setia

Aja nganti kegudha wanita liya

(Mas, if that's what you want

I can only wait

I can strengthen my heart without you

Mas, even though you go to work

I ask you to remain loyal

Don't be tempted by other women)

The song "Aku Cah Kerja" of "I am a Working Person" actually does not provide a new dimension of masculinity. This song actually reinforces the concept of traditional masculinity that divides the role between husband and wife. The husband focuses on productive work, while the wife focuses on reproductive work (Widodo, 2009). The husband works outside the house, while the wife focuses on work inside the house.

A husband and wife share a role in three things, namely decision making, financial management, and childcare. In carrying out these three roles, the Javanese couple prioritizes harmony in relationships so that all three roles are carried out flexibly (Putri \& Lestari, 2015). Meanwhile, related to the role of managing the family economy, in terms of earning a living, wives who choose to work must be prepared with the consequences of multiple roles, even though wives who play a double role like this tend not to pursue a career (Coltrane, 2004).

In the song "Aku Cah Kerja" or "I am a Working Person", it is not the role in the economic sector that is the end of the problems of married couples. The 
couple's problems are influenced by jealousy and suspicion and the desire to live together from the wife's side. Meanwhile, on the other hand, family needs require the husband to work away from the family. So, a married couple tries to equalize their views so that harmony in the relationship is maintained. Efforts to maintain harmony are carried out by the husband by convincing his wife to trust his decision. This is a dimension of masculinity in the husband, in the form of responsibility and a strong commitment to meet family needs. In addition, this song also represents the calmness of the husband in the face of his wife's ego. This effort was made for the sake of maintaining harmony in their marriage relationship.

\section{Emotional Dimension}

Modern life has changed the position of men and women in domestic relations. The dominance of men commonly found in married life has shifted to a form of female superiority. This is what is found in the song "Bojo Galak" or "Fierce Wife". This song by Pendhoza contains the author's outpouring of his fierce wife. The fierce nature makes his wife a superior figure in the family. Like it or not, the husband also follows the various rules of his wife's play in order to maintain the integrity of the relationship.

The principle of giving in to maintain the integrity of the marriage run by the husband is what create a new view of masculinity. Being calm in dealing with his wife signifies the emotional maturity of men. The following are a few excerpts that confirm this statement.

wis nasibe kudu kaya ngene

duwe bojo kok ra tau ngapenake

seneng muring, omongane sengak

kudu tak trima, bojoku pancen galak

(My fate should be this way

To have a wife who never comforts me

She likes to be mad at me

But I have to accept that my wife is fierce) 
This song begins with the surrender of men to his fate of having a fierce wife. His wife is described as seneng muring (often feels grumpy) and grumbling (speak rudely). However, the husband tried to sincerely accept the fate.

In the sentence kudu tak trimo, bojoku pancen galak (I must be willing to accept, my wife is indeed fierce) becomes a marker of explanation for the attitude of a husband who has stability or emotional calm in handling or facing his fierce wife. The emotional stability is a representation of the masculinity that a man or husband has towards his wife's unpleasant attitude.

saben dina rasane ora karuan

ngrasake bojoku sing ra tau perhatian

nanging piye maneh atiku wes kadung tresna

senajan batinku ngampet ana njero dada

(Every day feels bad day

I feel that my wife never cares

But I can't do anything cause I $m$ in love

Even though my heart holds the hurt)

In line with the first stanza, the second stanza of this song tells the story of a husband's feeling that he feels his days are filled with unpleasant things (saben dina rasane ora karuan). The husband never gets the attention of his wife by let alone served like the head of the family. His wife's attitude is growing resentment in his heart. However, the love that had grown and developed in his heart was able to defeat the feeling of annoyance.

In the second stanza the husband's attitude is reflected in the actions of his wife who is unable to care by raising his love rather than the emotional wounds that he experiences. It was written in the words "nanging piye maneh atiku wes kadung tresna / senajan batinku ngampet ana njero dada" (but what can I do, my heart is already in love, even though my heart is holding back the pain). The husband's actions signify high emotional maturity. The husband tries to dominate the love to calm emotions rather than thinking about the pain in his heart. This can be categorized in the characteristics of masculinity that is owned by the husband that is not emotional or always calm. 
tak tanpa nganggo tulusing ati

tak trima sliramu tekan saiki

mungkin wes dadi jodhone

senajan kahanane kaya ngene

(I accept her with sincerity

I accept you until the present

Maybe it has been my fate

Even though the situation is as bad as this)

The top of the emotional maturity of men is seen in the reffrain part of the song. Emotional maturity leads to a high level of religiosity about his fate, namely the belief that his fate is in God's hands. Living life with a partner that has been provided by God includes a religious attitude that is very important in the Islamic view (Thalib, 2015). So, even though the marriage life does not run harmoniously, the belief in a fate as God's destiny makes men tend to be willing to live it.

A fate about life partner can't be solely seen from the similarity in personality characteristics of a partner, but is more influenced by how the two undergo a relationship in one bond (Zentner, 2005). In the song "Bojo Galak", men prefer to enjoy a relationship with his wife, no matter how hard it is, rather than separating (nanging aku wegah pisah). At most far, men go out of the house to do 'ngopi' or hang out in a coffee shop just to release the burden of his life for a moment.

Kuat dilakoni yen ora kuat ditinggal ngopi

Tetep cinta, senajan bojoku galak

(If I am strong enough, I will live it.

If I am not, I will have a cup of coffee

I $m$ still in love even though my wife is fierce)

In a study, the disharmony of a husband and wife relationship was caused by work and satisfaction with their marriage. Work becomes an important measure for men, while wives prioritize satisfaction (Sayer et al., 2011). However, from these two factors, employment (economic problems) is not the 


\section{Ulya et al.- Representation of Javanese Masculinity}

dominant factor causing divorce (Eliason, 2012). In the case of the song "Bojo Galak", the disharmony of their marital relationship was not caused by these two reasons, but because of the character of each, especially the wife. The husband realizes that his wife's character is indeed fierce, so he accepts it willingly. In fact, when his wife is mad, the husband chose to remain silent.

yen wes ngono aku mung iso meneng

tak jelasno malah mung gawe kowe sepaneng

di matamu aku iki ora tau bener

kabeh mbok salahno rumangsa wis paling pinter

(If that happens, I can just stay calm

My explanation just makes you tense

In your eyes I'll never be right

You are the smartest then seeing that everyone else is wrong)

This is one dimension of masculinity that is unique to a male figure. On the one hand, men have force and power over women, but he chooses to give in to avoid conflict. This is considered as awareness of the most basic nature of marriage, namely the existence of commitment, not just love (Stassen \& Bates, 2010). In this case, men have a great awareness about commitment in marriage. This is the dimension of masculinity in men.

The song "Bojo Galak" represents the attitude of men of the modern era in living their domestic life. From this song, we can take the value that the concept of masculinity has undergone a change, from traditional masculinity with the symbols of men who nurture, dominate, and control, to be men who prioritize patience, love, and loyalty in order to maintain the integrity of the marriage.

In many aspects, this change occurred. In Indonesia, the phenomenon of the election of women regional leaders is evidence of the greater role and participation of women, Muslims in particular, in the public (Dewi, 2017). This public leadership also indirectly impacts on changes in domestic leadership in the family area. 


\section{Intellectual Dimension}

Intellectually, masculinity is characterized by a man who is logical, intelligent, rational, objective, and practical. These characteristics are also found in Javanese men, as illustrated in the lyrics of the dangdut koplo songs. One of the songs featuring an intellectual dimension is the song with title "Pikir Keri" or "Think about It Later". This song is a created by Andi Mbendhol which was popularized by female singer namely Via Vallen. Although sung by female singers, the masculine impression of this song is quite strong. This certainly cannot be separated from the views and life experiences of the song writer.

The song "Pikir Keri" depicts a man's logical, rational, objective, and relaxed attitude in addressing a problem, including problems originating from a spouse, wife, or girlfriend. Men tend to be more realistic than women. Men put forward logic and reason, while women rely on ego and feelings. Likewise in addressing the issue of love and fate in life partner.

This song contains the song writer's feelings of his lover. The song writer feels that his love affair with his lover is hung by uncertainty. The song writer's heart is likened to a kite being pulled and stretched out haphazardly. The promises of the lover are also often broken. In fact, the song writer's love for his girlfriend is so great.

In response to this, the arranger is realistic. He was aware of his inability to see what would happen next. Therefore, what will happen to a love relationship with his girlfriend, he acts "pikir keri" or think about it later. Most importantly, just go through what is in present. Thinking about something that is uncertain and unclear will only be a waste. It's better to think of other things which are more positive (Mending nyicil motor padha mumete / Nanging ana hasile ketimbang mikir kowe). (It's better to feel dizzy because of thinking about my motorbike's installment rather than thinking of you)

He also believes that the match will never be exchanged (Jodho bakal tekan ora bakal kijolan - Who is meant to, me will be mine) This belief makes him more relaxed to think of his lover later. Even if he does not have a relationship with his current lover, he can accept it sincerely. Here is a complete quote of the song "Pikir Keri". 
Pikir keri-Think about it later

Yen gelem tak jak rabi

Yen (o)ra gelem tak jagongi

Sing (o)ra penting pikir keri

Yen kowe gelem tak sayang

Ya aja mbok gawe bimbang

Rasah kakehan alesan

(if you want, you can accept my proposal

If you don't want it, I'll play the drum -- sing or have fun--

What is not important to me, I'll think about it later

If you want to accept my love

Don't you make me doubts

Don't make a lot of excuses)

The dangdut koplo song has unique thematic characteristics related to masculinity. Most of the dangdut koplo songs are written by male authors. Song inspiration comes from personal experience. Thus, although popularized by female singers, the masculine impression on these songs is still very dominant.

The dangdut koplo songs tell a lot about the relationship between men and women in various contexts. The relationship leads to three dimensions of Chafetz's masculinity, namely the functional dimension, emotional dimension, and intellectual dimension. Meanwhile, matters relating to physical, sexual, and interpersonal dimensions are not commonly found in the songs.

The relation of men and women to the lyrics of the dangdut koplo songs places men on the side who giving in. The term giving in here is not the same as losing or being defeated. The principle of giving in to men is done in order to maintain harmonious relations with their partners.

Not only be giving in, even men in the song "Bojo Galak" in the concept of Robert O'Mochain can be said to be victims of domestic violence 
(O’Mochain, 2018). So, emotionally, men show maturity and composure so far from the impression of violence, anger, and etc. What was found in this study has exceeded the results obtained by Lonngi regarding men's anger in relation to violence against women (Lonngi, 2017). Domestic violence cannot be seen from the point of view of only men or women because they both play a role. This is a consequence of globalization which results in new relations between men and women (Bustamante et al., 2019).

Examining the relations between men and women in contemporary society is a very complex work. This will always produce new concepts and dimensions in various ways. The study of femininity must be balanced with masculinity. Because the changes in the feminine dimension will definitely affect the masculine dimension. Globalization has a big impact in improving the capability and quality of life for women (Gray et al., 2006). This change will indirectly affect the dimension of masculinity. This new dimension is found in the lyrics of the dangdut koplo songs.

\section{The Impact of Masculinity from a Mass Communication Perspective}

The masculinity implication of dangdut song lyrics has an impact on dimensions of ideology, lifestyle, and personal images in the creative industry. The image becomes a perspective that will be internalized, especially in Javanese society through the lyrics, tones, and styles of performing the contents of the songs that are heard in daily basis. Language as a symbol of communication forms a habituation paradigm that changes thought patterns and values (Song, 2004). The songs heard by the Javanese people show a willingness to dominate, to be a priority, and unwilling to be defeated.

In line to images, the representation of masculinity in dangdut song lyrics is done by using signs and language. These signs and language to express masculinity are easily understood within the framework of the dominant ideology adopted by Javanese society. The most striking impact of internalizing the mindset of masculinity is the emergence of signs, symbols, and people's perspectives that position themselves as subjects (Sellnow, 1999). In the end, in the context of mass communication through songs, ideology becomes a tool for the material and cultural interests of its creator. 
Some emerging cases in society are shown by verbal violence against certain people who are cornered through dangdut song lyrics. This impression arises from the sensitivity experienced and acceptance that violates the agreed mass communication transactions. Ideology shapes the mindset of one party to be understood. The habit shown through dangdut song lyrics leads to opinion as an ideal form / causality between genders so that disputes that arise are often marked as harassment.

Based on the development of masculinity patterns in song lyrics, the problems of the global creative industry system in Indonesia are also increasing. Song lyrics are accepted by a certain group as a tool to open the world's eyes to the stereotypes of masculine images that have been formed so far (Oware, 2011). Psychologically, men should not be worried or indecisive. This impression is received by women or other minor gender who are disturbed or become victims of verbal violence or actions in everyday life (mass communication context).

Communication patterns emerging from masculinity also change the complexity in the big cities (Dudink et al., 2012). The identity of the song that is accepted by the Javanese community is able to change the mindset, perspective, and behavior of men, especially those who live in rural and transitional areas, as well as how and their reasons for determining the rhythm in the music they listen to. Based on the form of speech conveyed in the public domain, listening to dangdut songs emphasizes the extrovert, rude, aggressive, and rational character of men, while women are characterized by being introvert, soft, affective, and emotional. In receiving and delivering song messages, the creator or writer's perspective as a speaker also affects the messages' sensitivity partially and contextually so that the media's role is central (Sudaryanto et al., 2019).

The persuasion generated by the response given by the Javanese community after listening to dangdut songs (through lyrics and rhythm) shows an attitude of confidence. Meanwhile, women or minorities are led to the inability of individuals to believe that they can have beliefs which are different from other people. The social and creative cultural impacts that arise from the masculinity shown by the Javanese are a crisis of self-confidence, a tendency to close oneself, and a result of social rejection in the past. In this way, the inseparable perspective of a structuralist is to highlight the mutual influence 
of the subject, language, and society, and prioritize institutions, complexity, and the possibility of using power.

\section{Conclusion}

Dangdut Koplo songs raise three dimensions of masculinity, namely functional, emotional, and intellectual. The functional dimension places men in the role of breadwinners. The emotional dimension places men in a person with high emotional stability and maturity. Meanwhile, the intellectual dimension presents a male figure with logical, rational, and realistic thoughts. These three dimensions are seen from the relationship between men and women. Men tend to put themselves as the party who give in. The principle of giving in is carried out solely to maintain harmonious relations with their partners. This principle is in line with the Javanese saying, "Wani ngalah, luhur wekasane" which means the one who succumb or give in, is the one with great value. In addition, the belief in blessings, soul mate, and destiny outlined by God also influenced the emergence of a new dimension of masculinity in the lyrics of the dangdut koplo songs.

Apart from the erotic impression and plebeian pinned by some people about the dangdut koplo music, in fact, there is value that can be drawn in it. In its development, this dangdut can now be enjoyed by various groups. In fact, it has been able to penetrate the national market, no longer performed from stage to stage in the suburbs. Dangdut Koplo has been able to deliver several singers to be famous singers nationally and several performances in prestigious shows on television. This is proof that dangdut koplo not only gives a negative impression, but also presents some values. One of them is raising the problem of masculinity in it.

\section{References}

Albelda, J. S., \& Infantes, A. T. (2017). Logic practices in the process of construction of masculinity of Valencian men: Street, risk, football and ark. Masculinities and Social Change. https://doi.org/10.17583/mcs.2017.1937

Amzy, N., Pramudita, P., \& Pratama, D. (2019). Dangdut and the Concept of 
158 Ulya et al.- Representation of Javanese Masculinity

Khamr: Hermeneutic Analysis of Dangdut Koplo Performance. https://doi.org/10.4108/eai.8-12-2018.2283847

Barker, C. (2012). An Introduction to Cultural Studies. Cultural Studies

Theory and Practice. https://doi.org/10.4135/9781452204734

Bustamante, C. M., Quintal López, R. I., \& Amarís Macías, M. (2019). La

violencia Masculina en la Pareja como Proceso Relacional: Un Desafío de Superación Cultural. Masculinities \& Social Change, 8(3), 307-331. https://doi.org/10.17583/mcs.2019.3809

Campbell, K. E., \& Chafetz, J. S. (2000). Handbook of the Sociology of Gender. In Contemporary Sociology.

https://doi.org/10.2307/2654092

Coltrane, S. (2004). Elite careers and family commitment: It's (still) about gender. Annals of the American Academy of Political and Social Science, 596(1), 214-220.

https://doi.org/10.1177/0002716204268776

Decker, A. (2020). Hidden for Their Protection: Gendered Power,

Provocation, and Representation in Dangdut Competition Television.

Bijdragen Tot de Taal-, Land-En Volkenkunde/Journal of the

Humanities and Social Sciences of Southeast Asia, 176(1), 37-69.

Dewi, K. H. (2017). Piety and Sexuality in a Public Sphere: Experiences of Javanese Muslim Women's Political Leadership. Asian Journal of Women's Studies, 23(3), 340-362.

https://doi.org/10.1080/12259276.2017.1352250

Donaldson, M. (1993). What is hegemonic masculinity? Theory and Society. https://doi.org/10.1007/BF00993540

Dudink, S. P., Hagemann, K., \& Clark, A. (2012). Representing masculinity: Male citizenship in modern western culture. New York, NY: Palgrave Macmillan.

Eliason, M. (2012). Lost jobs, broken marriages. Journal of Population Economics, 25, 1365-1397. https://doi.org/10.1007/s00148-0110394-4

Gray, M. M., Kittilson, M. C., \& Sandholtz, W. (2006). Women and globalization: A study of 180 countries, 1975-2000. International Organization, 60(2), 293-333. https://doi.org/10.1017/S0020818306060176

Herd, D. (2009). Changing images of violence in Rap music lyrics: 19791997. Journal of Public Health Policy. https://doi.org/10.1057/jphp.2009.36 
Joanpere, M., \& Morlà, T. (2019). New Alternative Masculinities, the Struggle within and for the Feminism in Higher Education. HSE Social and Education History. https://doi.org/10.17583/MCS.2019.3936

Krause, A. E., \& North, A. C. (2019). Pop music lyrics are related to the proportion of female recording artists: Analysis of the United Kingdom weekly top five song lyrics, 1960-2015. Psychology of Popular Media Culture. https://doi.org/10.1037/ppm0000174

Krippendorff, K. (2004). Content Analysis: An Introduction to Its Methodology (second edition). In SAGE Publications.

https://doi.org/10.1103/PhysRevB.31.3460

Leap, B. (2019). A New Type of (White) Provider: Shifting Masculinities in Mainstream Country Music from the 1980s to the 2010s. Rural Sociology. https://doi.org/10.1111/ruso.12276

Lonngi, L. B. (2017). Analysis of male "anger" in the context of violence against women in order to design a framework for construction of responsibility. Masculinities and Social Change, 6(1), 39-61. https://doi.org/10.17583/mcs.2017.1923

Miles, M., \& Huberman, A. (1994). Miles and Huberman Chapter 2. In Qualitative Data Analysis.

Nurlian; Darulay, H. (2008). Kesetaraan Gender Dalam Pembagian Kerja Pada Keluarga Petani Ladang (Studi Kasus Analisa Isu Gender Pada Keluarga Petani Ladang di Desa Cot Rambong, Kecamatan Kuala, Kabupaten Nagan Raya, NAD). Jurnal Harmoni Sosial, II(2), 78-82.

O'mochain, R. (2018). La violencia sexual dirigida a hombres en conflictos: Un reto para los estudios de género. Masculinities and Social Change, 7(1), 1-23. https://doi.org/10.17583/MCS.2018.2986

Olson, D., DeFrain, J., \& Skogrand, L. (2013). Marriages and Families: Intimacy, Diversity, and Strengths (8th ed.). McGraw-Hill Education. Oware, M. (2011). Brotherly Love: Homosociality and Black Masculinity in Gangsta Rap Music. Journal of African American Studies. https://doi.org/10.1007/s12111-010-9123-4

Prorokova, T. (2017). Between Vietnam and 9/11: Arnold Schwarzenegger and a New Type of Masculinity in Twins and Kindergarten Cop. Masculinities \& Social Change. https://doi.org/10.17583/mcs.2017.2195

Putri, D. P. K. P., \& Lestari, S. (2015). Pembagian Peran dalam Rumah Tangga pada Pasangan Suami Istri Jawa. Jurnal Penelitian Humaniora, 16(1), 72-85. 
Sayer, L. C., England, P., Allison, P. D., \& Kangas, N. (2011). She left, he left: How employment and satisfaction affect women's and men's decisions to leave marriages. American Journal of Sociology, 116(6). https://doi.org/10.1086/658173

Sellnow, D. D. (1999). Music as Persuasion: Refuting Hegemonic

Masculinity in "He Thinks He'll Keep Her." Women's Studies in Communication, 22(1), 66-84.

Setiawan, S., \& Susanti, A. (2021). Sexuality In Dangdut Lyrics: A Critical Discourse Analysis. Psychology and Education Journal, 58(1), 32863295. https://doi.org/10.17762/pae.v58i1.1268

Song, G. (2004). The fragile scholar: Power and masculinity in Chinese culture (Vol. 1). Hong Kong University Press.

Stassen, H., \& Bates, B. (2010). Constructing Marriage: Exploring Marriage as an Ideograph. Qualitative Research Reports in Communication, 11(1), 1-5. https://doi.org/10.1080/17459430903412848

Sudaryanto, M., Mardapi, D., \& Hadi, S. (2019). How foreign speakers implement their strategies to listen indonesian language? Journal of Advanced Research in Dynamical and Control Systems.

Tandho, B., \& Rohidi, T. R. (2018). Dangdut Koplo Las Vegas Pati: The Analysis of Song form Structure and Creativity of Process. Catharsis, 7(1), 124-131.

Taylor, S. J., \& Bogdan, R. (1998). Introduction to Qualitative Research Methods (3rd ed.). John Wiley \& Sons.

Thalib, M. D. (2015). Takdir Dan Sunnatullah (Suatu Kajian Tafsir Maudhu'i). AL-ISHLAH: Jurnal Pendidikan Islam, 13(1), 28-38. https://doi.org/10.35905/ALISHLAH.V13I1.486

Vigorito, A. J., \& Curry, T. J. (1998). Marketing masculinity: Gender identity and popular magazines. Sex Roles. https://doi.org/10.1023/A:1018838102112

Weintraub, A. N. (2013). The Sound and Spectacle of Dangdut Koplo: Genre and Counter-Genre in East Java, Indonesia. Asian Music, 44(2), 160-194. https://doi.org/10.1353/amu.2013.0019

Widodo, S. (2009). Analisis peran perempuan dalam usahatani tembakau. Embryo, 6(2), 148-153. https://doi.org/ISSN 0216-0188

Zentner, M. R. (2005). Ideal mate personality concepts and compatibility in close relationships: A longitudinal analysis. Journal of Personality and Social Psychology, 89(2), 242-256. https://doi.org/10.1037/00223514.89.2.242 
Chafit Ulya is Lecturer in Indonesian Language Education Program at Universitas Sebelas Maret, Indonesia.

Ria Dwi Puspita Sari is Student in Indonesian Language Education Doctoral Program at Universitas Sebelas Maret, Indonesia.

Kundharu Saddhono is Associate Professor in Indonesian Language Education Program at Universitas Sebelas Maret, Indonesia

Memet Sudaryanto is Lecturer in Indonesian Language Education Program at Universitas Jenderal Soedirman, Indonesia

Contact Address: Direct correspondence to Chafit Ulya, Building E, Faculty of Teacher Training and Education, Universitas Sebelas Maret, 57126, Indonesia. email: chafit@staff.uns.ac.id 